\title{
Percutaneous ethanol injection into thyroid cysts
}

\author{
Tiroid kistlerine perkütan etanol enjeksiyonu \\ Bilal Çetin', Kazım Duman², Uğur Karapınar³, Ömer Sağlam4, Engin Dursun ${ }^{4}$ \\ ${ }^{1}$ Department of Otorhinolaryngology, Gümï̈ssuyu Military Hospital, Istanbul, Turkey \\ ${ }^{2}$ Department of General Surgery, Gïmïsssuyu Military Hospital, Istanbul, Turkey \\ ${ }^{3}$ Department of General Surgery, Bursa Military Hospital, Bursa, Turkey \\ ${ }^{4}$ Department of General Surgery, Kasımpaşa Military Hospital, Istanbul, Turkey
}

\begin{abstract}
Objective: To present the results of 28 patients who were treated by Doppler ultrasound guided percutaneous ethanol injection (PEI) into benign cystic thyroid nodules.

Methods: Before percutaneous injection of ethanol, malignancies were excluded with fine needle aspiration biopsy. Volume of the nodule was calculated according to length $\times$ width $\times$ depth $\times \pi / 6$ formula. During the application, $95 \%$ ethanol solution was injected about half of the initial cystic volume. At follow-up nodule diameter, formation of fibrosclerosis and nodule vascularization were evaluated. More than $50 \%$ reduction in nodule volume relative to the initial volume was defined success.

Results: The success rate with single application of PEI was found 88.5 percent. With administration of the second application of PEI on unsuccessful cases success rate increased to 92.9 percent.

Conclusion: Doppler ultrasound-guided PEI injection is a reliable, effective and inexpensive method in the treatment of thyroid cysts with high success rates.
\end{abstract}

Key words: Thyroid cyst, thyroid nodule, percutaneous ethanol injection cyst, Doppler ultrasonography.

Thyroid nodule which is one of the most frequently encountered thyroid diseases is characterized by growth of abnormal tissues into the thyroid gland. Its incidence varies among populations, and geographic regions. Nowadays, thanks to more frequent use of imaging modalities, thyroid nodules have been detected in individuals with complaints, and many asymptomatic patients as well. The incidence of thyroid nodules in our country is estimated to be 33.3 percent. ${ }^{[1]}$ Thyroid nodules have been classified as solid, and

\section{Özet}

Amaç: Benign kistik tiroid nodülü olan ve Doppler ultrasonografi eşliğinde perkütan etanol enjeksiyonu (PEİ) uygulaması ile tedavi edilen 28 hastamızın sonuçları sunuldu.

Yöntem: Perkütan etanol enjeksiyonu uygulamasından önce tüm hastalarda ince iğne aspirasyon biyopsisi ile malignite dışlandı. Kist hacmi uzunluk $\times$ yükseklik $\times$ en $\times \pi / 6$ formülü kullanılarak hesapland. Uygulamada başlangıç kist hacminin yarısı kadar \% 95'lik etil alkol kullanıldı. Hastalarımızın takiplerinde nodül çapı, fibroskleroz oluşumu ve nodül vaskülarizasyonu değerlendirildi. Başlangıç hacmine göre \% 50'den fazla küçülme başarı olarak kabul edildi.

Bulgular: Bir PEİ uygulaması ile hastalarımızın \%88.5'inde tedavi edildi. Başarısız olgularda ikinci uygulamayla tedavi oranı \%92.9'a yükseldi.

Sonuç: Tiroid kistlerinin tedavisinde ultrason eşliğinde PEİ uygulaması yüksek başarı oranlarıyla etkili, ucuz ve güvenilir bir tedavi yöntemidir.

Anahtar sözcükler: Tiroid kisti, tiroid nodülü, perkütan etanol enjeksiyonu, Doppler ultrasonografi.

cystic based on the anatomic structure of the lesion. While majority of the nodules demonstrates benign characteristics, malignant nodules have been also reported in various frequencies. Though malignancy is more frequently encountered in solid lesions, many studies have indicated that cystic lesions can be malignant as well, and clinical findings, and demographic data of the patients might fail to discriminate between benign, and malign lesions. ${ }^{[2]}$
Correspondence: Bilal Cetin, MD. Department of Otorhinolaryngology,

Gümüşşuyu Military Hospital, İstanbul, Turkey.

e-mail: drbilalcetin@gmail.com

Received: June 19, 2013; Accepted: August 14, 2013; Published online: January 29, 2014
Online available at:

www.jmedupdates.org doi:10.2399/jmu.2013003007

QR code: 
Conventional treatment of thyroid nodules is surgical excision. In simple benign cystic thyroid nodules, cosmetic reasons, local compression, and pain are the most frequently seen treatment indications. Conventional surgery for smaller lesions is not preferred by surgeons. Besides, complications mostly related to open surgery as bleeding, wound site infection, recurrent nerve damage, and scar formation have prompted surgeons to opt for minimally invasive surgical methods. To that end, many procedures like cyst aspiration, injection of sclerotic agents into the cyst, radiofrequency ablation of the cyst or laser photofulguration have been employed..$^{[3-7]}$

Increased recurrence rates after simple cyst aspiration, higher cost of laser or radiofrequency ablative procedures have been the most important disadvantages of these methods. Application in a short time as a day care surgery on ambulatory patients with its minimal, and acceptable side effects, and lower cost can be regarded as advantages of ethanol injection. In this study, in the light of literature findings, we aimed to present results of our patients with benign cystic thyroid nodules whom we treated using percutaneous ethanol injection (PEI).

\section{Materials and Methods}

Medical files of 28 adult patients who had been treated by PEI with the diagnosis of cystic thyroid nodule between the years 2005, and 2011 were retrospectively evaluated. Initial examination findings (detailed physical examination of head, and neck region together with indirect laryngoscopic examination), thyroid hormone tests, and ultrasonographic (US) examination reports of the neck region were assessed.

Doppler US-guided PEI was recommended for all patients with recurrent cysts detected during routine controls made after initial diagnostic aspiration biopsy which had been reported as a benign cyst. The procedure was applied after written informed consent forms were obtained from patients. Thyroid hormone test results within normal limits, normal head and neck physical examination, and also indirect laryngoscopic findings, and initial aspiration biopsy material from cystic nodule reported histopathologically as benign were determined as eligible inclusion criteria.

Surgical intervention was performed using local anesthesia under US guidance without any sedation in the radiology suit. As a first step, dimensions, and volume of the cyst were determined with the aid of US. Volume of the cyst was calculated by using the formula:
Volume of the cyst $=$ length $(\mathrm{mm}) \times$ height $(\mathrm{mm}) \times$ width $(\mathrm{mm}) \times \pi / 6$

Contents of the cyst were aspirated using an 18-gauge injector needle under ultrasonographic guidance. A solution of $95 \%$ ethyl alcohol equal to about half of the total volume of the aspirated cystic fluid was injected into the cyst. The solution was left 10 minutes in situ, and then contents of the cyst were aspirated before termination of the procedure. All measurements, and PEI procedure were realized by the same surgeon.

All patients who underwent PEI procedures were scheduled for a postprocedural control visit at $3 \mathrm{rd}$ month. At control visits, the patients were reevaluated with physical examination, and ultrasound. Presence (if any), and volume of the cyst, intracystic fibrosis, and vascularity were evaluated on US. More than 50\% decrease from the baseline volume was accepted as procedural success. Percutaneous ethanol injection procedure was repeated for recalcitrant cases, and they were reevaluated 3 months later. Surgical excision was recommended for refractory patients, and those with persistent complaints after two PEI procedures.

\section{Results}

A total of 28 patients (18 females, and 10 males) were included in our study. Mean age of the patients was 38.39 $(20.55 \pm 10.03)$ years. All patients met predetermined procedural criteria for PEI. Mean cyst volume was $8.08 \pm 3.92$ (range: $2.7-20) \mathrm{ml}$ at baseline.

After a single dose of PEI cyst disappeared in 7 (25\%) patients, and decreased in volume more than $50 \%$ in 16 (57.1\%) patients. Success rate after a single dose of PEI was 88.5 percent. For patients whose cysts decreased more than $50 \%$, additional therapy was not contemplated, and annual follow-ups were recommended.

Five patients with persistent complaints whose cysts did not decrease in volume more than $50 \%$ compared with baseline underwent a second PEI at 3rd month with resultant decrease in cyst volume more than $50 \%$ in $3(10.7 \%)$ patients for whom control visits were recommended. Surgical excision was recommended for the remaining two (7.1\%) patients whose cyst volumes did not shrink. When results of both procedures were evaluated in combination, two doses of PEI achieved a success rate of $92.9 \%$ in cystic thyroid nodules.

A mean thyroid cyst volume of $0.92 \pm 1.4$ (range: $0-7$ ) $\mathrm{ml}$ was detected on the first control US examination performed at 3rd month. Excluding two patients with failed 
outcomes, decreases in fibrosis formation, and vascularization were observed. Patients ( $\mathrm{n}=6$ patients; $21.42 \%$ ) complained only of a local burning sensation felt during ethanol infiltration. We did not observe any postprocedural complication.

\section{Discussion}

The first step in the selection process of the treatment modality for thyroid cysts is to decide whether the cyst is benign or malign. To that end, cyst contents should be aspirated, and aspirate should be examined histopathologically. This approach has both diagnostic and therapeutic implications. Even only aspiration of the cyst can heal some patients. However, depending on the volume and the number of aspirations, recurrence rates ranging between 10 and $80 \%$ have been reported. ${ }^{[8,9]}$

Management of thyroid cysts using percutaneous ethanol injection was first reported by Edmonds et al. in 1987. ${ }^{[10]}$ US-guided PEI was originally recommended by Livraghi in $1990 .^{[11]}$ In a study performed by Verges et al. indicated that ethanol injections without the guidance of US is an effective treatment of benign thyroid cysts in especially developing regions where US is hardly available. ${ }^{[12]}$

Various studies have reported use of ethanol during PEI procedures at rates of 95,96 , and 99 percent. ${ }^{[13-15]}$ The volume of the ethanol solution to be injected has been estimated according to the volume of the aspirate. Some authors recommended solution to be injected should be equal to the total volume of the aspirate, while others suggested volume of the injection should be one-half of the aspiration fluid. Aspiration is repeated 10 minutes after ethanol injection. However, content of the cyst is very thick requiring injectors with increased caliber needles (ie $16 \mathrm{G}$ ) ${ }^{[16]}$ In our PEI procedures, we injected $95 \%$ ethyl alcohol solution using 18 $\mathrm{G}$ needles. We preferred to inject alcohol solution with a volume equal to the amount of the aspirate.

Success rates have been reportedly changed between 65 , and $90 \%$ in the literature studies where the success was accepted as more than $50 \%$ decrease in the cyst volume following PEI procedures. ${ }^{[15,17-19]}$ Similarly in our study, a $50 \%$ decrease in the cyst volume relative to baseline was considered as procedural success. Success rates achieved after the first, and second PEIs were 88.5, and $92.9 \%$, respectively. These results were in compliance with those of the other literature studies.

At 3 and 6 months after application of PEI, the patients should be controlled, and their response to treatment should be evaluated. Various authors have emphasized safe- ty, and reliability of the procedure especially for cystic lesions bigger than $40 \mathrm{ml}$ during their 10 years of followup. ${ }^{[17]}$

Following PEI, cutaneous ecchymosis, transient dysphonia, unilateral vocal cord paralysis, and Horner syndrome have been reported. However, generally speaking reports have stated improved tolerability of the procedure. Local pain, and a mild fever have been the most frequently reported postprocedural adverse effects. ${ }^{[18]}$ The most frequently seen adverse effect in our patients was local burning sensation. Before the procedure a local anesthetic was infiltrated on the percutaneous access site to increase tolerability of the patients which avoided the necessity of postprocedural auxillary therapy.

\section{Conclusion}

In conclusion, in the management of benign thyroid cysts, Doppler US-guided percutaneous ethanol injection is a cost-effective, and efficient treatment modality with higher success rates. It is a relatively safe procedure with very low complication rates, and improved patient tolerability. It should be priorly considered in patients who have met criteria for surgical management of thyroid cysts. Though short-term outcomes of PEI are promising, it can be difficult to determine when, and under which conditions cyst might recur in the long run. This issue can be clarified in studies performed with a larger scale patient populations followed up for a long-term.

Conflict of Interest: No conflicts declared.

\section{References}

1. Tanriover O, Comunoglu N, Eren B, et al. Occult papillary thyroid carcinoma: prevalence at autopsy in Turkish people. Eur J Cancer Prev 2011;20:308-12.

2. De losSantos ET, Keyhani-Rofagha S, Cunningham JJ, Mazzaferri EL. Cystic thyroid nodules. The dilemma of malignant lesions. Arch Intern Med 1990;150:1422-7.

3. Roh JL, Park C 2nd. Treatment of benign thyroid cysts by intracystic injection of OK-432. Surgery 2008;144:775-9.

4. Garg MK, Satija L, Khanna SK, Saini JS. Intracystic tetracycline therapy for hypofunctioning cystic thyroid nodules. J Assoc Physicians India 2000;48:891-4.

5. Lee JH, Kim YS, Lee D, Choi H, Yoo H, Baek JH. Radiofrequencyablation (RFA) of benign thyroid nodules in patients within completely resolved clinical problems after ethanol ablation (EA). World J Surg 2010;34:1488-93.

6. Døssing H, Bennedbaek FN, Hegedüs L. Beneficial effect of combined aspiration and interstitial laser therapy in patients with benign cystic thyroid nodules: a pilot study. Br J Radiol 2006;79 (948):943-7. 
7. Cho YS, Lee HK, Ahn IM, et al. Sonographically guided ethanol sclerotherapy for benign thyroid cysts: result in 22 patients. AJR Am J Roentgenol 2000;174:213-6.

8. Clark OH, Okerlund MD, Cavalieri RR, Greenspan FS. Diagnosis and treatment of thyroid, parathyroid, and thyroglossal duct cysts. J Clin Endocrinol Metab 1979;48:983-8.

9. 7.Jensen F, Rasmussen SN. The treatment of thyroid cysts by ultrasonically guided fine needle aspiration. Acta Chir Scand 1976; 142:209-11.

10. Edmonds CJ, Telle ZM. Thyroid cysts and their managements. Br Med J 1987;295:529-33.

11. Livraghi T, Paracchi A, Ferrari C, Reschini E, Nacchi RM, Bonifaino A. The treatment of autonomous thyroid nodules with percutaneous ethanol injection: 4 year experience. Radiology 1994; 190:529-33.

12. Vergès B, Buffier P, Baillot-Rudoni S, Brindisi MC, Bouillet B, Petit JM. Non-ultrasound-guided ethanol sclerotherapy for the treatment of thyroid cysts. Ann Endocrinol (Paris) 2011;72:203-7.

13. Monzani F, Lippi F, Goletti O, et al. Percutaneous aspiration and ethanol sclerotherapy for thyroid cysts. J Clin Endocrinol Metab 1994;78:800-2.
14. Bartos M, Pomorski L, Narebski J. The treatment of solitary thyroid nodules in non-toxic goiter with $96 \%$ ethanol injections. [Article in Polish] Wiad Lek 1999;52:432-40.

15. Bennedbaek FN, Hegedüs L. Treatment of recurrent thyroid cysts with ethanol: a randomized double-blind controlled trial. J Clin Endocrinol Metab 2003;88:5773-7.

16. Sung JY, Baek JH, Kim YS, et al. One-step ethanol ablation of viscous cystic thyroid nodules. AJR Am J Roentgenol 2008;191:17303.

17. Del Prete S, Caraglia M, Russo D, et al. Percutaneous ethanol injection efficacy in thetreatment of large symptomatic thyroid cystic nodules: ten-year follow-up of a large series. Thyroid 2002;12: 815-21.

18. Chu CH, Chuang MJ, Wang MC, Lam HC, Lu CC, Lee JK. Sclerotherapy of thyroid cystic nodules. J Formos Med Assoc 2003; 102:625-30.

19. Kim JH, Lee HK, Lee JH, Ahn IM, Choi CG. Efficacy of sonographically guided percutaneous ethanol injection for treatment of thyroid cysts versus solid thyroid nodules. AJR Am J Roentgenol 2003;180:1723-6.

This is an open access article distributed under the terms of the Creative Commons Attribution-NonCommercial-NoDerivs 3.0 Unported (CC BYNC-ND3.0) Licence (http://creativecommons.org/licenses/by-nc-nd/3.0/) which permits unrestricted noncommercial use, distribution, and reproduction in any medium, provided the original work is properly cited.

Please cite this article as: Çetin B, Duman K, Karapınar U, Sağlam Ö, Dursun E. Percutaneous ethanol injection into thyroid cysts. J Med Updates 2013;3(3):142-145. 